\title{
Influenza
}

\author{
(C) (ब) $\Theta$ OPEN ACCESS
}

\author{
Sam Ghebrehewet consultant in communicable disease control and head of health protection ${ }^{1}$, \\ Peter MacPherson academic clinical lecturer ${ }^{123}$, Antonia Ho specialty registrar in infectious diseases ${ }^{4}$ \\ 5
}

${ }^{1}$ Cheshire and Merseyside Health Protection Team, Public Health England North West, Liverpool, UK; ${ }^{2}$ Department of Public Health and Policy, The Farr Institute@HeRC, University of Liverpool, UK; ${ }^{3}$ Department of Clinical Research, Liverpool School of Tropical Medicine, Liverpool, UK; ${ }^{4}$ Department of Infectious Diseases, Queen Elizabeth University Hospital, Glasgow, UK; Institute of Infection and Global Health, University of Liverpool, Liverpool, UK

The World Health Organisation estimates that approximately one billion people are infected and up to 500000 people die from influenza each year. ${ }^{1}$ The greatest burden of illness usually occurs among children, while the highest burden of severe disease (in terms of hospitalisation and death) occurs in those with underlying medical conditions, infants and young children, and elderly people. ${ }^{2}$ Current circulating influenza strains in humans include influenza $\mathrm{A}(\mathrm{H} 1 \mathrm{~N} 1) \mathrm{pdm} 09$, influenza $\mathrm{A}(\mathrm{H} 3 \mathrm{~N} 2)$, and both influenza $\mathrm{B}$ viruses (B/Victoria and $\mathrm{B} / \mathrm{Yamagata}){ }^{3}{ }^{4}$ This article provides non-specialists with information on how to diagnose, manage, and prevent flu.

\section{What is influenza virus?}

There are four types of influenza viruses: influenza A, B, C, and $\mathrm{D},{ }^{3-6}$ but only influenza $\mathrm{A}$ and $\mathrm{B}$ viruses cause clinically important human disease and seasonal epidemics (table $1 \Downarrow$ ). ${ }^{1}$ Influenza A viruses cause the most severe clinical disease and are the commonest cause of seasonal epidemics and pandemics in human populations. ${ }^{1}$

\section{What are the symptoms of influenza?}

Influenza is characterised by sudden onset of fever, myalgia, headache, malaise, dry cough, sore throat, and nasal congestion (fig $1 \Downarrow$ ). ${ }^{13-15}$ Gastrointestinal symptoms including nausea, vomiting and diarrhoea are also common. ${ }^{16}$ The incubation period of influenza (time from infection to development of symptoms) is 1 to 4 days. ${ }^{17}$ Viral shedding, when the virus is infectious, usually occurs from one day before the onset of symptoms, to 5-7 days after. ${ }^{18-20}$

Influenza can cause severe illness or death, particularly in high risk populations (box 1). ${ }^{23}$ Mortality is higher among individuals with complicated influenza (illness necessitating hospital admission, or an exacerbation of an underlying chronic illness) across all age groups, but is highest in infants aged 6 months or younger. ${ }^{2}$

\section{How do influenza epidemics and pandemics occur?}

Minor changes that occur in virus proteins between influenza seasons (known as antigenic drift) result in annual epidemics, with winter peaks in temperate regions (November-April in the northern hemisphere, and May-October in the southern hemisphere, see fig $2 \Downarrow)$. ${ }^{3}$ In tropical and subtropical regions the seasonality of influenza is less well defined (fig $2 \Downarrow$ ). ${ }^{24}{ }^{25}$

In contrast, pandemics (severe global epidemics) of influenza occur when a new influenza A subtype emerges abruptly because of a major shift in the proteins on the virus surface (antigenic shift), often because of combination with viruses circulating in animals. ${ }^{26}$ As most people have no immunity to the new subtype, infection spreads quickly (table $2 \Downarrow$ ).

\section{How is influenza diagnosed?}

Most influenza is diagnosed clinically in the community at times when the virus is known to be circulating. Patients admitted to hospital may have respiratory samples taken for testing by polymerase chain reaction (PCR), rapid antigen test, or immunofluorescence assay. With respiratory outbreaks in a closed setting (such as care homes, schools, hospitals) nasal swabs may be taken from the first few symptomatic individuals to identify the responsible organism. 


\section{What you need to know}

- Influenza is an acute viral infection of the respiratory tract that spreads easily from person to person

- Influenza is usually self limiting in healthy individuals, with recovery in 3-7 days

- Elderly people, children under 6 months old, pregnant women, and people with chronic conditions or immunosuppression are at increased risk of complications

- Offer influenza vaccination to people at risk of complications and increased influenza exposure, as well as to young children, who are efficient infection spreaders

- People in high risk groups may benefit from antiviral therapy, hospitalisation, or intensive care

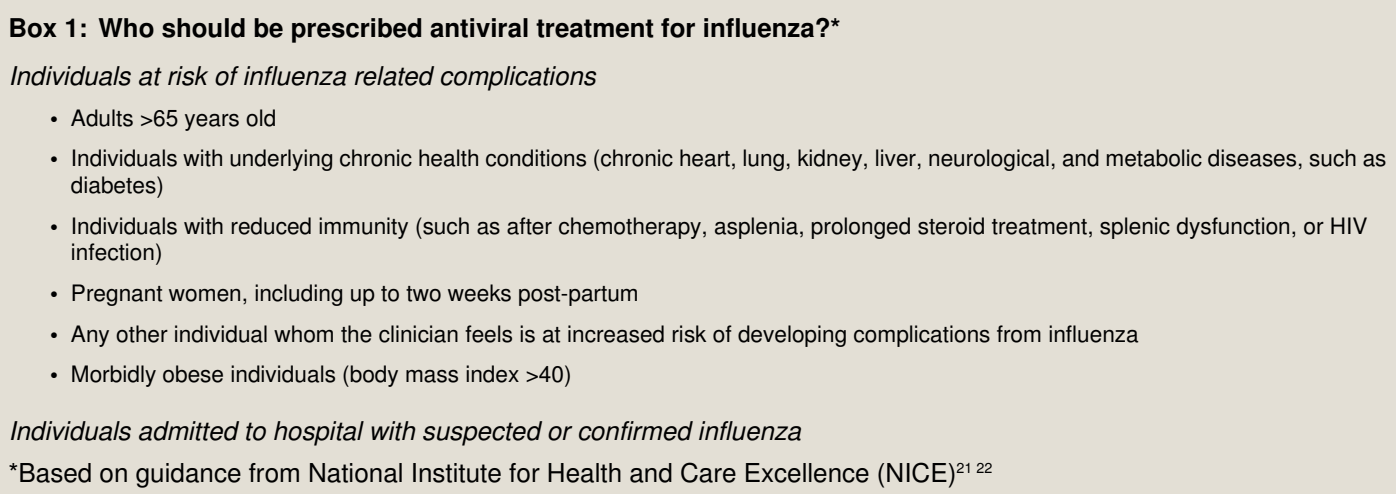

\section{What treatments are available for influenza?}

Influenza is usually self limiting in healthy individuals. Treatment of uncomplicated disease in healthy individuals is supportive and includes antipyretics, adequate fluid intake, rest, and staying off work or school until 24 hours after resolution of fever to limit spread to others. ${ }^{21}$

Most randomised trials of antiviral drugs have been conducted among otherwise healthy individuals and have shown modest reductions in symptom duration ( 0.7 days). ${ }^{27}$ Fewer studies have been conducted among individuals at risk of complicated influenza. Data from observational studies and trials suggests that antiviral treatment may reduce adverse outcomes. ${ }^{28-30}$ For example, the meta-analysis from 2015 reported fewer lower respiratory tract complications requiring antibiotics after oseltamivir treatment compared with placebo (risk difference $-3.8 \%$ ) and fewer hospital admissions (risk difference $-1.1 \%$ ). ${ }^{30}$ NICE ${ }^{21}$ Public Health England, ${ }^{12}$ UK Chief Medical Officers, ${ }^{31}$ and the $\mathrm{WHO}^{32}$ recommend treatment of suspected and confirmed influenza for individuals at risk of complicated influenza (box 1). General practitioners considering prescription of antivirals should discuss with patients likely benefits, as well as possible harms including nausea (number treated to cause nausea in one patient $=28$ ) $^{27}$ and vomiting (number treated to cause vomiting in one patient $=22$ ). ${ }^{27}$

Individuals with complicated influenza may be helped by antiviral treatment. ${ }^{21}{ }^{22}$ Treatment is most effective if started within 48 hours of symptom onset, and it should not be delayed while awaiting results of investigations. ${ }^{12}{ }^{28}$ Neuraminidase inhibitors oseltamivir and zanamivir inhibit viral release from infected cells and reduce the rate of viral replication. Meta-analysis of individual participant data found that, compared with late treatment, early treatment (within 48 hours of symptom onset) of hospitalised individuals with complicated influenza reduced the odds of mortality by $52 \% .{ }^{28}$ Some individuals may require antibiotic therapy to treat secondary bacterial infections.

\section{How can influenza be prevented? Vaccination}

Vaccination is the most effective means of preventing influenza and its complications. Immunity developed in one influenza season may not provide protection in future years mainly because of changes in circulating strains, antigenic drift, and waning immunity. Influenza vaccines are updated annually to include the viral strains that are predicted to circulate in winter. ${ }^{34}$ Box 2 lists the UK recommendations for vaccination. ${ }^{23}$ Vaccination schedules may vary internationally, and so it is important to check local policies. In healthy adults, trivalent inactivated vaccines have an overall vaccine efficacy of $60 \% .^{33} 34$ Newer quadrivalent vaccines are being increasingly adopted due to the broader protection provided by the inclusion of an additional influenza $B$ virus. ${ }^{35-38}$

Since 2013, the UK influenza vaccination programme has been extended to children aged 2-4 years, with planned phased introduction to children of school ages, ${ }^{23}$ as it reduces morbidity by directly protecting children and provides indirect protection to vulnerable groups (such as grandparents) by reducing transmission in the community. ${ }^{39}$ Attenuated live nasal spray formulation is recommended in children aged $2-<17$ years based on its superior efficacy and greater immunity against mismatched strains compared with inactivated vaccines. ${ }^{41-43}$ Studies have found that inactivated influenza vaccines cannot cause influenza disease and are safe in pregnancy. ${ }^{44-47}$

Common side effects of vaccination include local injection site reactions and cold-like symptoms. Fever, malaise, and myalgia are less common.$^{33}$ Contraindications include confirmed severe allergic reaction (anaphylaxis) to a previous influenza vaccine or to any component of the vaccine. ${ }^{23}$ Live attenuated influenza vaccine (LAIV) should not be given to children or adolescents with severe immunodeficiency or to those taking salicylate treatments because of the risk of Reye's syndrome. ${ }^{23}$ LAIV is also not recommended for pregnant women or adults with immunosuppression. ${ }^{23}$ 


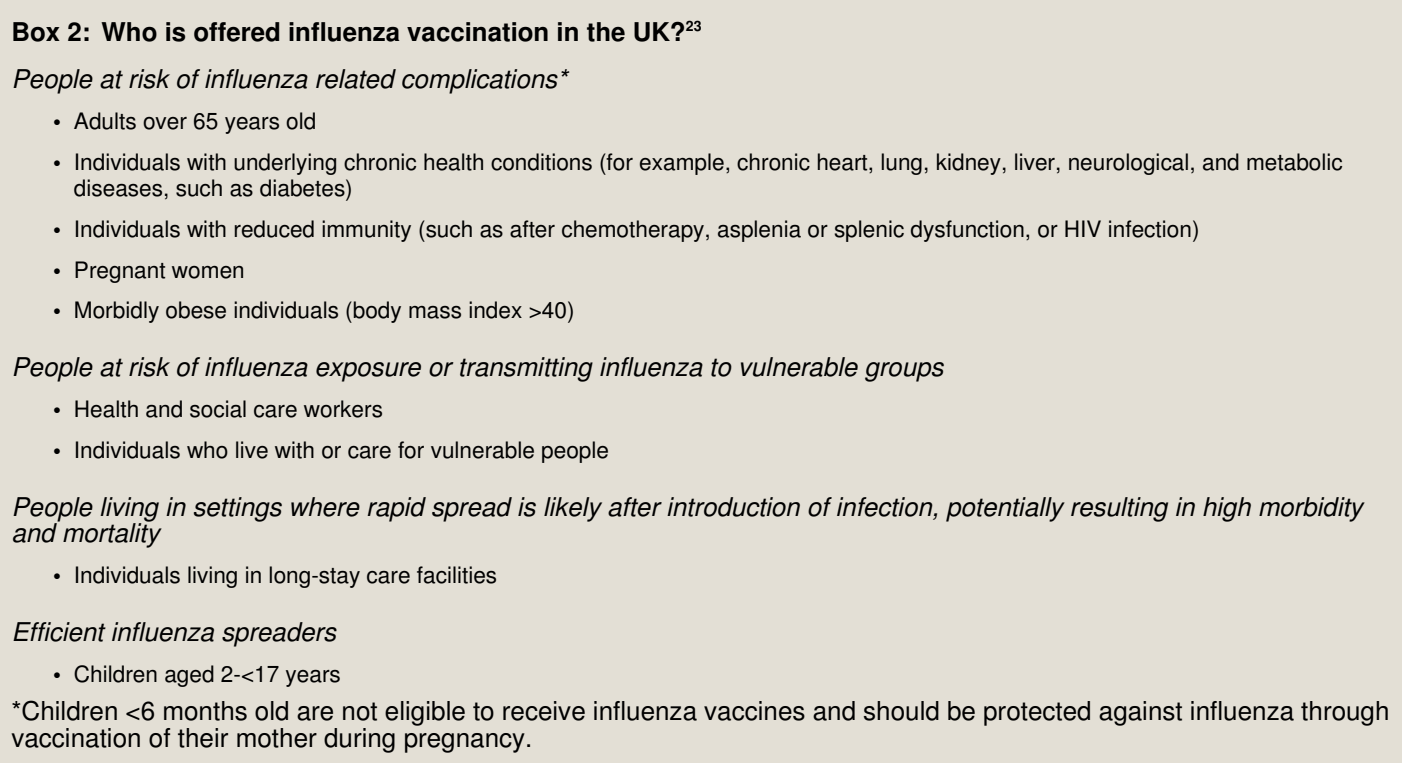

\section{Antiviral chemoprophylaxis}

Influenza may be prevented or rendered less severe by post-exposure prophylaxis (PEP) with antivirals (oseltamivir and zanamivir). ${ }^{27}{ }^{48} \mathrm{NICE}^{21}$ and Public Health England ${ }^{12}$ recommend that, when influenza is circulating, antivirals are offered to those who are:

- In at-risk groups (box 2) and

- Who have had close contact with people with confirmed or suspected influenza (that is, living in the same household or residential setting) and

- Able to start prophylaxis within 48 hours (oseltamivir) or 36 hours (zanamivir) of contact and

- Have not received vaccination in the current influenza season, or who have been vaccinated $<14$ days since contact or where there is significant mismatch between vaccine and circulating strains, or during an outbreak in a closed setting regardless of vaccination history.

\section{Infection control and isolation}

Although published evidence for effectiveness is limited, hand and cough hygiene are likely to be important interventions to reduce influenza spread in the community, as well as in closed settings (table $3 \Downarrow$ ).

During an outbreak, consider isolation of residents of closed settings for the duration of the infectious period (five days after symptom onset) to limit spread to others. Cohorting of patients (that is, in separate hospital bays or on separate floors of a residential home) may be necessary. Residential homes may need to be closed to new admissions until the outbreak is controlled. Care must be taken when discharging a patient from a ward with a known influenza outbreak to a care home, or vice versa.

\section{New developments in prevention and treatment of influenza}

Vaccine candidates have recently been developed that can elicit antibodies against multiple influenza strains, and thus could overcome the need for annual influenza vaccines. ${ }^{55-57}$ Several antiviral drugs are currently in development for influenza treatment, including favipiravir, ${ }^{58}$ nitazoxanide,${ }^{59}{ }^{60}$ and arbidol. ${ }^{6162}$

Contributors: $S G$ and $P M$ conceived of the review. SG is the guarantor of the manuscript. SG, PM, and AH undertook the literature review, and were supported by Dr Bethan Roberts, foundation year 2 trainee in health protection, Cheshire and Merseyside Health Protection Team, Public Health England North West. SG, PM, and AH contributed to writing drafts of the manuscript. PM designed and wrote code for the interactive application. All authors have seen and approved the final manuscript version.

Competing interests: We have read and understood BMJ policy on declaration of interests and declare that we have no competing interests.

Provenance and peer review: Not commissioned; externally peer reviewed.

1 World Health Organization. Influenza (seasonal)—Fact sheet No 211. 2014. www.who. int/mediacentre/factsheets/s211/en/.

2 Cromer D, van Hoek AJ, Jit M, Edmunds WJ, Fleming D, Miller E. The burden of influenza in England by age and clinical risk group: a statistical analysis to inform vaccine policy. $J$ Infect 2014;68:363-71. doi:10.1016/j.jinf.2013.11.013 pmid:24291062.

3 World Health Organization. Global Influenza Surveillance and Response System (GISRS). 2016. www.who.int/influenza/gisrs_laboratory/en/.

4 World Health Organization. Influenza vaccine viruses and reagents. 2016. www.who.int/ influenza/vaccines/virus/en/.

5 Ferguson L, Eckard L, Epperson WB, et al. Influenza D virus infection in Mississippi beef cattle. Virology 2015;486:28-34. doi:10.1016/j.virol.2015.08.030 pmid:26386554.

6 Hause BM, Collin EA, Liu R, et al. Characterization of a novel influenza virus in cattle and Swine: proposal for a new genus in the Orthomyxoviridae family. MBio 2014;5:e00031-14 doi:10.1128/mBio.00031-14 pmid:24595369.

7 A revision of the system of nomenclature for influenza viruses: a WHO memorandum. Bull World Health Organ 1980:58:585-91.pmid:6969132.

8 Webster RG, Bean WJ, Gorman OT, Chambers TM, Kawaoka Y. Evolution and ecology of influenza A viruses. Microbiol Rev 1992;56:152-79.pmid:1579108.

9 Olson DR, Heffernan RT, Paladini M, Konty K, Weiss D, Mostashari F. Monitoring the impact of influenza by age: emergency department fever and respiratory complaint surveillance in New York City. PLoS Med 2007;4:e247. doi:10.1371/journal.pmed. 0040247 pmid:17683196.

10 Kawai S, Nanri S, Ban E, et al. Influenza vaccination of schoolchildren and influenza outbreaks in a school. Clin Infect Dis 2011;53:130-6. doi:10.1093/cid/cir336 pmid: 21690619.

11 Matsuzaki Y, Sugawara K, Furuse Y, et al. Genetic Lineage and Reassortment of Influenza C Viruses Circulating between 1947 and 2014. J Virol 2016;90:8251-65. doi:10.1128/JVI. 00969-16 pmid:27384661.

12 Public Health England. PHE guidance on use of antiviral agents for the treatment and prophylaxis of seasonal influenza. Version 7.0. PHE, 2016.

13 Lam PP, Coleman BL, Green K, et al. Predictors of influenza among older adults in the emergency department. BMC Infect Dis 2016;16:615. doi:10.1186/s12879-016-19664 pmid:27793117.

14 Monto AS, Gravenstein S, Elliott M, Colopy M, Schweinle J. Clinical signs and symptoms predicting influenza infection. Arch Intern Med 2000;160:3243-7. doi:10.1001/archinte. 160.21.3243 pmid: 11088084

15 Ohmit SE, Monto AS. Symptomatic predictors of influenza virus positivity in children during the influenza season. Clin Infect Dis 2006;43:564-8. doi:10.1086/506352 pmid:16886147.

16 Minodier L, Charrel RN, Ceccaldi PE, et al. Prevalence of gastrointestinal symptoms in patients with influenza, clinical significance, and pathophysiology of human influenza 


\section{Sources and selection criteria}

We searched PubMed and the Cochrane Library databases (search terms "influenza," "flu," "influenza-like illness"). We obtained information on the epidemiology of influenza from annual reports produced by authoritative bodies and organisations such as Public Health England (PHE), Centers for Communicable Disease Prevention and Control (CDC), and the World Health Organization (WHO). We reviewed up-to-date influenza guidelines and reviews, including those published by PHE, Cochrane Reviews, and the National Institute for Health and Care Excellence (NICE).

\section{Education into practice}

-What steps have you taken to improve the uptake of influenza vaccination among staff and eligible patients under your care?

- Have you reviewed your organisation's infection control policy for responding to an outbreak of influenza-like illness?

- Have you reviewed antivirals prescribed (treatment or prophylaxis) for eligible patients with influenza and their close contacts?

\section{Further educational resources}

- Public Health England. Chapter 19: Influenza. In: Immunisation Against Infectious Disease. 2013, updated 2015. www.gov.uk/ government/uploads/system/uploads/attachment_data/file/456568/2904394_Green_Book_Chapter_19_v10_0.pdf

- National Institute for Health and Care Excellence. Clinical Knowledge Summaries: Influenza-seasonal. https://cks.nice.org.uk/influenzaseasonal

- Public Health England. Flu Plan: Winter 2016/17. www.gov.uk/government/uploads/system/uploads/attachment_data/file/525967/ Annual_flu_plan_2016_to_2017.pdf

- Wellcome Trust \& Academy of Medical Sciences. Use of neuraminidase inhibitors in influenza. 2015. www.acmedsci.ac.uk/policy/ policy-projects/treating-influenza/

\section{How patients were involved in the production of this article}

No patients were involved in the production of this article

viruses in faecal samples: what do we know? Virol J 2015;12:215. doi:10.1186/s12985015-0448-4 pmid:26651485.

17 Lessler J, Reich NG, Brookmeyer R, Perl TM, Nelson KE, Cummings DA. Incubation periods of acute respiratory viral infections: a systematic review. Lancet Infect Dis 2009:9:291-300. doi:10.1016/S1473-3099(09)70069-6 pmid:19393959.

18 Department of Health. Routes of transmission of the influenza virus: scientific evidence base review. DoH, 2011.

19 Killingley B, Greatorex J, Digard P, et al. The environmental deposition of influenza virus from patients infected with influenza $\mathrm{A}(\mathrm{H} 1 \mathrm{~N} 1)$ pdm09: Implications for infection prevention and control. J Infect Public Health 2016;9:278-88. doi:10.1016/j.jiph.2015.10.009 pmid: 26653976.

20 Lau LLH, Cowling BJ, Fang VJ, et al. Viral shedding and clinical illness in naturally acquired influenza virus infections. J Infect Dis 2010;201:1509-16. doi:10.1086/652241 pmid: 20377412.

21 National Institute for Health and Care Excellence. Clinical Knowledge Summaries: Influenza-seasonal. 2015. https://cks.nice.org.uk/influenza-seasonal.

22 National Institute for Health and Care Excellence. Amantadine, oseltamivir and zanamivir for the treatment of influenza (technology appraisal guidance 168). 2009. www.nice.org. uk/Guidance/ta168.

23 Public Health England. Chapter 19: Influenza. In: Immunisation Against Infectious Disease. 2013, updated 2015. www.gov.uk/government/uploads/system/uploads/attachment_data/ file/456568/2904394_Green_Book_Chapter_19_v10_0.pdf

24 Viboud C, Alonso WJ, Simonsen L. Influenza in tropical regions. PLoS Med 2006;3:e89. doi:10.1371/journal.pmed.0030089 pmid:16509764

25 Moura FE. Influenza in the tropics. Curr Opin Infect Dis 2010;23:415-20. doi:10.1097/ QCO.0b013e32833cc955 pmid:20644472.

26 World Health Organization. Pandemic influenza preparedness and response. WHO, 2010

27 Jefferson $T$, Jones MA, Doshi $P$, et al. Neuraminidase inhibitors for preventing and treating influenza in healthy adults and children. Cochrane Database Syst Rev 2014;4:CD008965.pmid:24718923.

28 Muthuri SG, Venkatesan S, Myles PR, et al. PRIDE Consortium Investigators. Effectiveness of neuraminidase inhibitors in reducing mortality in patients admitted to hospital with influenza A H1N1pdm09 virus infection: a meta-analysis of individual participant data. Lancet Respir Med 2014;2:395-404. doi:10.1016/S2213-2600(14)70041-4 pmid:24815805.

29 Zambon M. Developments in the treatment of severe influenza: lessons from the pandemic of 2009 and new prospects for therapy. Curr Opin Infect Dis 2014;27:560-5. doi:10.1097/ QCO.0000000000000113 pmid:25333476.

30 Dobson J, Whitley RJ, Pocock S, Monto AS. Oseltamivir treatment for influenza in adults: a meta-analysis of randomised controlled trials. Lancet 2015;385:1729-37. doi:10.1016/ S0140-6736(14)62449-1 pmid:25640810.

31 Department of Health. Chief Medical Officer and Chief Pharmaceutical Officer: advice on using antiviral medicines: influenza season 2015 to 2016. DoH, 2016 .

32 World Health Organization. WHO Guidelines for pharmacological management of pandemic influenza $A(H 1 N 1) 2009$ and other influenza viruses. WHO, 2010.

33 Demicheli V, Jefferson T, Al-Ansary LA, Ferroni E, Rivetti A, Di Pietrantonj C. Vaccines for preventing influenza in healthy adults. Cochrane Database Syst Rev 2014;3:CD001269.pmid:24623315.

34 Kliner M, Keenan A, Sinclair D, Ghebrehewet S, Garner P. Influenza vaccination for healthcare workers in the UK: appraisal of systematic reviews and policy options. BMJ Open 2016;6:e012149. doi:10.1136/bmjopen-2016-012149 pmid:27625062.
35 Beran J, Peeters M, Dewé W, Raupachová J, Hobzová L, Devaster JM. Immunogenicity and safety of quadrivalent versus trivalent inactivated influenza vaccine: a randomized, controlled trial in adults. BMC Infect Dis 2013;13:224. doi:10.1186/1471-2334-13-224 pmid: 23688546.

36 Kieninger D, Sheldon E, Lin WY, et al. Immunogenicity, reactogenicity and safety of an inactivated quadrivalent influenza vaccine candidate versus inactivated trivalent influenza vaccine: a phase III, randomized trial in adults aged $\geq 18$ years. BMC Infect Dis 2013;13:343. doi:10.1186/1471-2334-13-343 pmid:23883186.

37 Pépin S, Donazzolo Y, Jambrecina A, Salamand C, Saville M. Safety and immunogenicity of a quadrivalent inactivated influenza vaccine in adults. Vaccine 2013:31:5572-8. doi:10. 1016/j.vaccine.2013.08.069 pmid:24016810.

38 Tinoco JC, Pavia-Ruz N, Cruz-Valdez A, et al. Immunogenicity, reactogenicity, and safety of inactivated quadrivalent influenza vaccine candidate versus inactivated trivalent influenza vaccine in healthy adults aged $\geq 18$ years: a phase III, randomized trial. Vaccine 2014;32:1480-7. doi:10.1016/j.vaccine.2014.01.022 pmid:24486352.

39 Baguelin M, Flasche S, Camacho A, Demiris N, Miller E, Edmunds WJ. Assessing optimal target populations for influenza vaccination programmes: an evidence synthesis and modelling study. PLoS Med 2013:10:e1001527. doi:10.1371/journal.pmed.1001527 pmid: 24115913.

40 Loeb M, Russell ML, Moss L, et al. Effect of influenza vaccination of children on infection rates in Hutterite communities: a randomized trial. JAMA 2010;303:943-50. doi:10.1001/ jama.2010.250 pmid:20215608.

41 Belshe RB, Edwards KM, Vesikari T, et al. CAIV-T Comparative Efficacy Study Group. Live attenuated versus inactivated influenza vaccine in infants and young children. NEngl J Med 2007;356:685-96. doi:10.1056/NEJMoa065368 pmid:17301299.

42 Fleming DM, Crovari P, Wahn U, et al. CAIV-T Asthma Study Group. Comparison of the efficacy and safety of live attenuated cold-adapted influenza vaccine, trivalent, with trivalent inactivated influenza virus vaccine in children and adolescents with asthma. Pediatr Infect Dis J 2006;25:860-9. doi:10.1097/01.inf.0000237797.14283.cf pmid:17006278.

43 Ambrose CS, Luke C, Coelingh K. Current status of live attenuated influenza vaccine in the United States for seasonal and pandemic influenza. Influenza Other Respir Viruses 2008;2:193-202. doi:10.1111/j.1750-2659.2008.00056.x pmid:19453395.

44 Englund JA, Mbawuike IN, Hammill H, Holleman MC, Baxter BD, Glezen WP. Maternal immunization with influenza or tetanus toxoid vaccine for passive antibody protection in young infants. J Infect Dis 1993;168:647-56. doi:10.1093/infdis/168.3.647 pmid:8354906.

45 Zaman K, Roy E, Arifeen SE, et al. Effectiveness of maternal influenza immunization in mothers and infants. N Engl J Med 2008;359:1555-64. doi:10.1056/NEJMoa0708630 pmid: 18799552.

46 Naleway AL, Irving SA, Henninger ML, et al. Vaccine Safety Datalink and Pregnancy and Influenza Project. Safety of influenza vaccination during pregnancy: a review of subsequent maternal obstetric events and findings from two recent cohort studies. Vaccine 2014;32:3122-7. doi:10.1016/j.vaccine.2014.04.021 pmid:24742490.

47 Tamma PD, Ault KA, del Rio C, Steinhoff MC, Halsey NA, Omer SB. Safety of influenza vaccination during pregnancy. Am J Obstet Gynecol 2009;201:547-52. doi:10.1016/j.ajog. 2009.09.034 pmid:19850275.

48 National Institute for Health and Care Excellence. Oseltamivir, amantadine and zanamivir for the prophylaxis of influenza (technology appraisal guidance 158). 2008. www.nice.org. uk/guidance/ta158.

49 Public Health England. Infection control precautions to minimise transmission of respiratory tract infections (RTIs) in the healthcare setting. PHE, 2014. 
50 Siegel J, Rhinehart E, Jackson M, Centers for Disease Control and Prevention. Guideline for isolation precautions: preventing transmission of infectious agents in healthcare settings. CDC, 2007.

51 Health and Safety Executive. Pandemic flu—workplace guidance. HSE, 2016

52 European Centre for Disease Prevention and Control (ECDC). Technical document. Safe use of personal protective equipment in the treatment of infectious diseases of high consequence: A tutorial for trainers in healthcare settings. Version 2, 2014.

53 Public Health England. PHE guidelines on the management of outbreaks of influenza-like illness in care homes. 2016. www.gov.uk/government/publications/acute-respiratorydisease-managing-outbreaks-in-care-homes.

54 Public Health England. Managing outbreaks of acute respiratory disease in care homes. 2012 (and supplement 2014). www.gov.uk/government/publications/acute-respiratorydisease-managing-outbreaks-in-care-homes.

55 Impagliazzo A, Milder $\mathrm{F}$, Kuipers $\mathrm{H}$, et al. A stable trimeric influenza hemagglutinin stem as a broadly protective immunogen. Science 2015;349:1301-6. doi:10.1126/science. aac7263 pmid:26303961.

56 Yassine HM, Boyington JC, McTamney PM, et al. Hemagglutinin-stem nanoparticles generate heterosubtypic influenza protection. Nat Med 2015;21:1065-70. doi:10.1038 nm.3927 pmid:26301691.

57 Joyce MG, Wheatley AK, Thomas PV, et al. NISC Comparative Sequencing Program. Vaccine-induced antibodies that neutralize group 1 and group 2 influenza A viruses. Cell 2016;166:609-23. doi:10.1016/j.cell.2016.06.043 pmid:27453470.

58 Furuta Y, Gowen BB, Takahashi K, Shiraki K, Smee DF, Barnard DL. Favipiravir (T-705), a novel viral RNA polymerase inhibitor. Antiviral Res 2013;100:446-54. doi:10.1016/]. antiviral.2013.09.015 pmid:24084488.
59 Rossignol JF, La Frazia S, Chiappa L, Ciucci A, Santoro MG. Thiazolides, a new class of anti-influenza molecules targeting viral hemagglutinin at the post-translational level. $J$ Biol Chem 2009;284:29798-808. doi:10.1074/jbc.M109.029470 pmid:19638339.

60 Haffizulla J, Hartman A, Hoppers M, et al. US Nitazoxanide Influenza Clinical Study Group. Effect of nitazoxanide in adults and adolescents with acute uncomplicated influenza: a double-blind, randomised, placebo-controlled, phase $2 \mathrm{~b} / 3$ trial. Lancet Infect Dis 2014;14:609-18. doi:10.1016/S1473-3099(14)70717-0 pmid:24852376.

61 Leneva IA, Russell RJ, Boriskin YS, Hay AJ. Characteristics of arbidol-resistant mutants of influenza virus: implications for the mechanism of anti-influenza action of arbidol. Antiviral Res 2009;81:132-40. doi:10.1016/j.antiviral.2008.10.009 pmid:19028526.

62 Pécheur El, Borisevich V, Halfmann P, et al. The synthetic antiviral drug arbidol inhibits globally prevalent pathogenic viruses. J Virol 2016;90:3086-92. doi:10.1128/JVI.0207715 pmid:26739045.

Published by the BMJ Publishing Group Limited. For permission to use (where not already granted under a licence) please go to http://group.bmj.com/group/rights-licensing/ permissions

This is an Open Access article distributed in accordance with the Creative Commons Attribution Non Commercial (CC BY-NC 3.0) license, which permits others to distribute, remix, adapt, build upon this work non-commercially, and license their derivative works on different terms, provided the original work is properly cited and the use is non-commercial. See: http://creativecommons.org/licenses/by-nc/3.0/. 


\section{Tables}

\section{Table 1| Influenza viruses}

\begin{tabular}{|c|c|c|c|}
\hline $\begin{array}{l}\text { Influenza } \\
\text { type }\end{array}$ & Classification & Reservoir & At risk groups \\
\hline \multirow[t]{4}{*}{$A$} & $\begin{array}{l}\text { - Classified into subtypes on the basis of haemagglutinin }(\mathrm{H}) \text { and } \\
\text { neuraminidase }(\mathrm{N}) \text { antigens on the surface of the viral envelope }\end{array}$ & \multirow{4}{*}{$\begin{array}{l}\text { The primary reservoir is aquatic } \\
\text { birds, but viruses also circulate } \\
\text { among many other species, such } \\
\text { as pigs, horses, and sea mammals }{ }^{8}\end{array}$} & \multirow{4}{*}{$\begin{array}{l}\text { Infects people of all ages, but } \\
\text { disproportionately causes severe disease in } \\
\text { older adults and individuals with underlying } \\
\text { chronic health problems }\end{array}$} \\
\hline & $\begin{array}{l}\text { - To date, } 18 \text { haemagglutinin subtypes and } 11 \text { neuraminidase } \\
\text { subtypes have been identified }\end{array}$ & & \\
\hline & $\begin{array}{l}\text { - Only three haemagglutinin types }(\mathrm{H} 1, \mathrm{H} 2 \text {, and } \mathrm{H} 3) \text { are } \\
\text { recognised to cause epidemic disease in humans }\end{array}$ & & \\
\hline & $\begin{array}{l}\text { - Nomenclature includes the virus type and subtype, natural host } \\
\text { species, geographical origin, year of isolation, and strain number } \\
\text { (such as H1N1/A/duck/Alberta/35/76) }{ }^{7}\end{array}$ & & \\
\hline B & $\begin{array}{l}\text { Divided into lineages on the basis of the haemagglutinin } \\
\text { glycoprotein }\end{array}$ & Mainly infects humans & $\begin{array}{l}\text { Children are affected by influenza B infection } \\
\text { at a disproportionately higher rate among the } \\
\text { general population }^{910}\end{array}$ \\
\hline C & $\begin{array}{l}\text { Unlike influenza A or B, which have two glycoproteins (HA and } \\
\mathrm{NA} \text { ), influenza C has only one glycoprotein (HEF) }\end{array}$ & Mainly infects humans & $\begin{array}{l}\text { Affects individuals of all ages, but tends to } \\
\text { cause mild illness }{ }^{11}\end{array}$ \\
\hline $\mathrm{D}$ & $\begin{array}{l}\text { Little known about it, but is thought to be related to influenza } \mathrm{C} \\
\text { viruses }\end{array}$ & Mainly infects pigs and cattle & Not known to cause human disease ${ }^{5}$ \\
\hline
\end{tabular}


Table 2| Antigenic drift versus antigenic shift: implications for epidemics and pandemics

Antigenic drift

Antigenic shift

Accumulation of mutations in genes that code for antibody binding sites on viruses A sudden major change in the virus antigenicity leading to emergence of new strains

Only one virus strain (accumulation of point mutations) From one or more virus strains (from genome reassortment)

Occurs frequently Occurs occasionally

Usually responsible for seasonal influenza epidemics and affects effectiveness of Gives rise to pandemics, which occur irregularly and unpredictably due to a influenza vaccine lack of immunity to the new strain in the human population

Occurs in influenza virus $A, B$, and $C$ Only occurs in influenza virus A 


\begin{tabular}{|c|c|c|c|c|}
\hline \multirow[b]{2}{*}{ Interventions } & \multicolumn{2}{|c|}{ Community setting } & \multirow[t]{2}{*}{ Care home setting } & \multirow{2}{*}{$\begin{array}{l}\text { Acute clinical } \\
\text { setting }\end{array}$} \\
\hline & At-risk patients & Low risk patients & & \\
\hline Isolation of patients ${ }^{49} 50$ & $\begin{array}{c}\text { Avoid contact with other at-risk } \\
\text { people and exclude from work, } \\
\text { school, or childcare until } \\
\text { asymptomatic }\end{array}$ & $\begin{array}{l}\text { Avoid contact with at-risk people and } \\
\text { exclude from work, school, or } \\
\text { childcare until asymptomatic }\end{array}$ & Yes $^{*}$ & Yes \\
\hline Use of PPE including surgical masks ${ }^{5152}$ & Not recommended & Not recommended & Yes & Yes \\
\hline $\begin{array}{l}\text { Implementation of rigorous infection } \\
\text { control procedures (hand hygiene; cough } \\
\text { etiquette; environmental cleaning and } \\
\text { waste disposal) }{ }^{49}{ }^{5153}\end{array}$ & $\begin{array}{l}\text { Provide advice on hand hygiene and } \\
\text { correct cough etiquette }\end{array}$ & $\begin{array}{l}\text { Provide advice on hand hygiene and } \\
\text { correct cough etiquette }\end{array}$ & Yes & Yes \\
\hline Symptomatic management ${ }^{21}$ & Yes & Yes & Yes & Yes \\
\hline $\begin{array}{l}\text { Antiviral therapy for patients with } \\
\text { influenza }\end{array}$ & Recommended & Not recommended & Recommended $\dagger$ & Recommended $\dagger$ \\
\hline $\begin{array}{l}\text { Regular review to assess for clinical } \\
\text { deterioration }^{12}\end{array}$ & Yesł & Not recommended & Yesł & Yes \\
\hline
\end{tabular}

*If not possible or practical, consider cohorting of patients as soon as possible.

†Consider post-exposure prophylaxis for other at-risk patients and residents in hospitals and care home settings.

$\ddagger$ Have low threshold for referring to secondary care. 


\section{Figures}

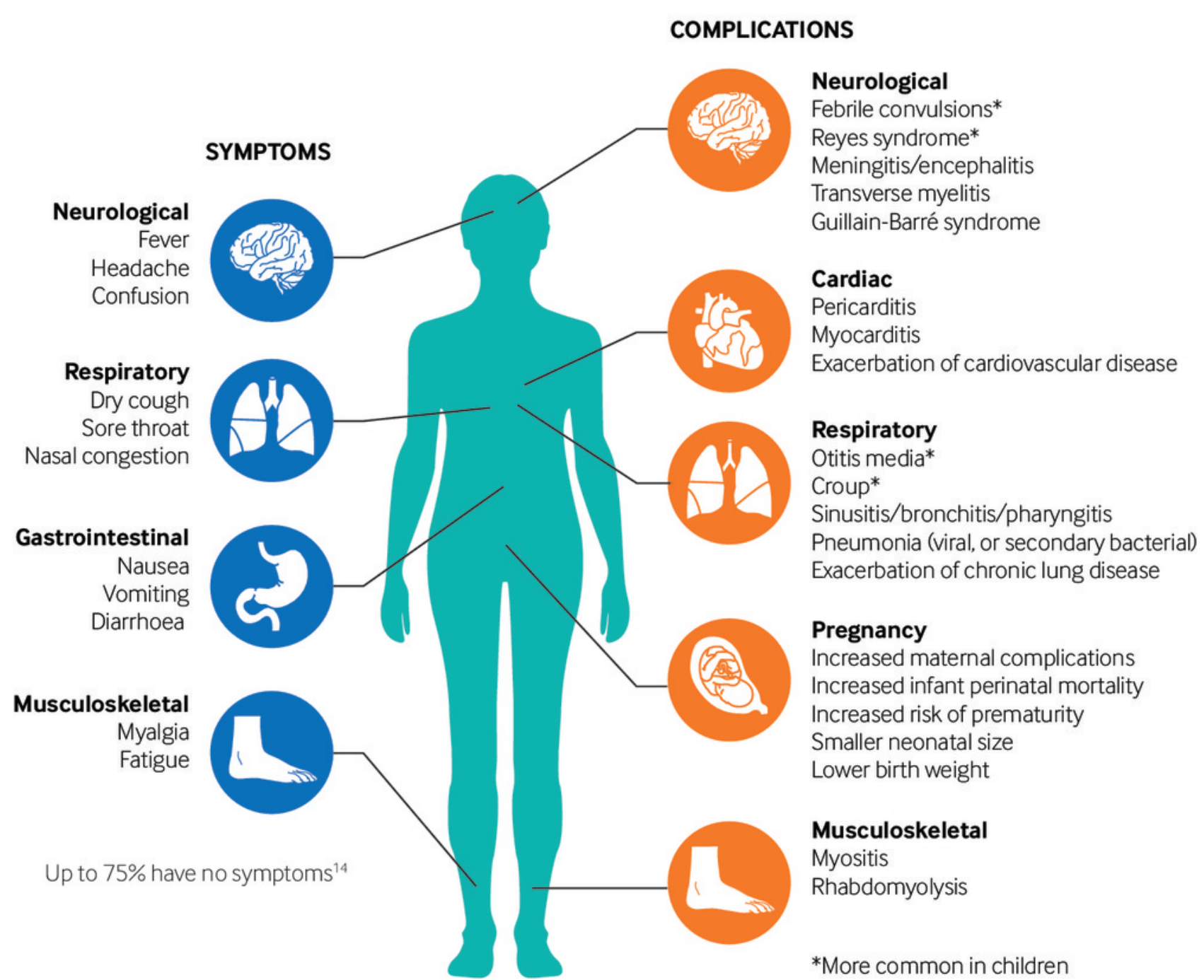

Fig 1 Symptoms and complications of influenza. Complicated influenza is defined as an infection that requires hospital admission $^{12}$ 


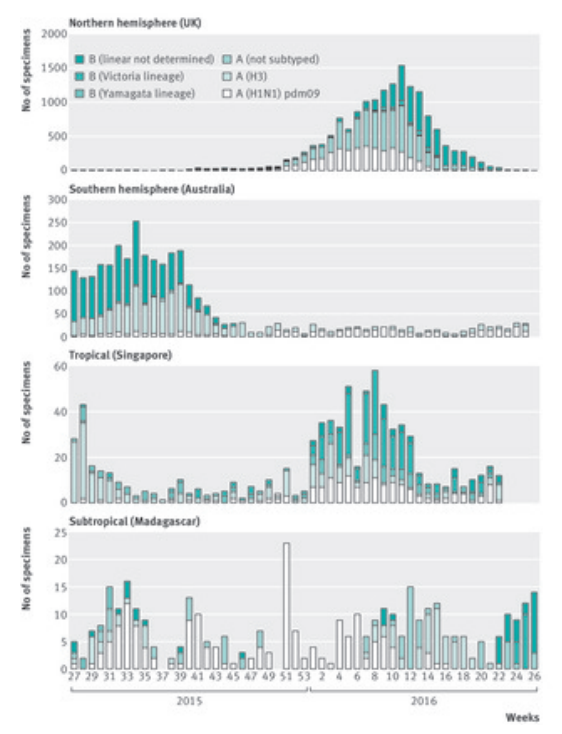

